\title{
The effects of environmental factors on leeches
}

\author{
Naim Saglam \\ Department of Aquaculture and Fish Diseases, Firat University, Turkey
}

Correspondence: Naim Saglam, Department of Aquaculture and Fish Diseases, Faculty of Fisheries, Firat University, 231 I 9 Elazig, Turkey,Tel +904242370000, Email naim.saglam@gmail.com

Received: February 06, 2018 | Published: February 08, 2018

Copyright $\odot 2018$ Saglam. This is an open access article distributed under the terms of the Creative Commons Attribution License, which permits unrestricted use, distribution, and reproduction in any medium, provided the original author and source are credited.

\begin{abstract}
Leeches are indispensable organisms of the aquatic ecosystem. The worldwide are identified over than 650 species of leeches. These organisms live in freshwater, estuarine, marine, and semi-terrestrial ecosystems. Leeches occur in slow flowing parts of streams and rivers, in artificial and natural lakes, in marine, in habitats such as marsh and lagoon. Leeches are found in the zone of the benthic and occasionally pelagic communities of artificial and natural lakes, ponds, marine, habitats such as marshes and lagoons and slow flowing parts of streams and rivers. Some species of leech are parasitic, and most are fed predators. Some species of leeches, which have undertaken important tasks in the ecosystem, are also endangered.Leeches, which are a member of the Clitellata class, are at the forefront of aquatic organisms affected by environmental negativity. In particular, human-induced environmental pressures are the most important factors that put the generation of leeches at risk. Leeches are most affected by agricultural activity, excessive collection, dangerous chemical compounds in water, increasing urbanization and global climate change.
\end{abstract}

Keywords: leeches, environmental effects, climate change, human pressure

\section{Introduction}

Leeches are members of the Annelida phylum, which is fed as sucking blood or a predator in wetlands. Worldwide, more than 650 species of leeches in the Hirundine class have been identified in the freshwater, estuarine, and semi-terrestrial ecosystems. With the development of genetic science, new leech species have been discovered in this class and changes in some known species names. ${ }^{1-5}$ Leeches are most important and dependable indicators of water quality and biodiversity in ecosystem, thus, the presence of specific leech species is often closely related to basic aquatic circumstances and the presence of certain animals. However, leeches are largely ignored in many ecological and environmental research projects or simply identified only as Hirudinea. ${ }^{2}$

Blood sucker leeches live as temporary ectoparasite on fish, frogs, turtles, snake and some mammals. Some leech species are fed as predator on the invertebrates, other individuals of Annelida, water snails and insect larvae. Leeches are one of the most important components of freshwater lakes, streams, rivers and in many marine and terrestrial habitats.In addition, leeches constitute the most important element of fish diet in their habitat. Therefore, leeches are often grown commercially on various farms for fish bait. . $^{1,3} 5$

Sanguivorous leech species are being researched extensively in order to reveal therapeutic pharmacological components on the salivary secretions Especially the leech species in the Hirudogenus are widely used in human treatment in worldwide. ${ }^{6-10}$ For this reason, leeches which are used for treatment in private leech farms are produced and allowed to be used in sterile conditions. ${ }^{3,11}$
There are six species of medicinal leeches (Hirudomedicinalis, $H$. verbana, $H$. orientalis, Hirudotroctina, H. nipponia and H. sulukii) in the Hirudogenus. The most well-known medical leech species are $H$. medicinalisand $H$. verbana, the last discovered is $H$. sulukii. ${ }^{12}$ Medicinal leeches in Hirudogenus are endangered species due to overuse and environmental restrictions. For this reason, these leech species are an important group.

Especially the marshlands and the lakes are closed basins, so the effects of the environmental pressure compounds are lethal on the leech species that live in these environments.There is not enough study on the effects on leeches, which have slow-moving although the effects to the aquatic organisms of environmental damage and pollution has been investigated.

\section{Agricultural effects on leeches}

Wetlands have been used for agriculture for centuries. However, wetlands offer a number of important ecosystem services, such as irrigation of agricultural land, clean water supply. However, the value of these services is sometimes underestimated. In some areas, the drainage and dry of wetlands for agriculture has been widespread. Some agricultural practices lead to increased levels of nutrients and pollutant loads (in the form of pesticides, fertilisers and animal faeces). Regulation and remediation of rivers and wetlands with agricultural purposes change the duration and extent of flows, affecting critical life stages of water dependent species including leeches. Some of the largest impacts are through the drainage or conversion of wetlands to cultivated land and the
Submit your Article | www.ologyjournals.com/submit-article OP Ology 
disturbance of ecosystem functions due to heavy machinery use or livestock presence. ${ }^{13}$

The life of leeches in wetlands are limited as a result of the agricultural pressures listed above. Some leeches die due to pesticides and pollutants or lose their spawning andbreeding environments. The pesticide application of agricultural fields from the air causes the polluters to reach the wetlands more easily and to kill the leeches.

Nitrate and phosphate fertilizers used in agricultural land can deteriorate ecological balance and biodiversity by reaching wetlands with surface flow during rainy seasons. As a result, some leech species in the wetland may disappear immediately, but the number of other some invertebrate animals could increase instead of leeches.

\section{Endocrine-disrupting compounds}

Endocrine-disrupting compounds (EDCs) come from a variety of man-made sources, such as persistent organic pollutants, pesticides, plastics, pharmaceuticals, ordinary household chemicals and industrial chemicals. Some are pervasive and widely dispersed in water environments, where they accumulate or are biomagnified. ${ }^{14-15}$ EDCs are pollutants that have the ability to alter the growth, reproduction and general embryonic and morphologic development of an aquatic organism. EDCs can be found in agricultural pesticides, alkylphenolics (e.g. detergents) found in industrial and municipal effluents, and natural hormones and synthetic steroids found in municipal effluent and agricultural runoff. ${ }^{16}$ EDCs in natural ecosystems are increasingly drawing researcher and public attention. These chemical agents affect aquatic life and its reproduction and can eventually cause reduced population density and biodiversity. At present, EDCs are being considered as possible reasons for the functional degradation of aquatic ecosystems. Molecular investigations show that EDCs exhibit genotoxicity and can destroy genetic diversity and structure. Historical statistics and ecological risk estimation provided strong data to prove that EDCs contribute to population density and biomass decline. ${ }^{15}$

In the context of the adverse effects of EDCs on the biomass and biodiversity in the wetlands listed above; EDCs can cause anomaly leech offspring, deformities in leech embryos and disruption of leech reproduction. In addition, EDCs can prevent leeches from laying eggs and cause sterile the leech cocoons. Therefore, EDCs may be a latent cause of aquatic species (especially endangered leech species) loss or extinction.

\section{Effect of urbanization on leeches}

Urban areas are increasing rapidly day by day. This area has an important pressure and disproportionate effect on wetlands. ${ }^{17}$ It is inevitable to transfer directly of sediment and other materials to the streams and other waters during the construction of the roads. ${ }^{18-19}$ This road construction wastes with precipitate may kill the leeches and destroy the cocoon breeding fields in wetlands.

\section{Effects of leech utilization on Hirudospecies}

The use of medical leeches for therapeutic and treatment purposes has kept people's brains busy for centuries. The first recorded use of medicinal leeches dates back to the beginning of civilisation. Leeches can be seen in wall paintings found in sepulchre of ancient Egypt in1567-1308 B.C The use of leeches spread rapidly in Paris Hospitals of France between 1772-1832. The use of leeches became so popular during this period that the species became endangered in Europe. Patients were prescribed up to 80 leeches a session. In 1833 alone, annual medicinal leech consumption in France hospitals approached 100 million. The ever-increasing demand made prices soar, and the French government granted awards to companies who could improve production by developing new stocks from marshes, streams and ponds. Leech harvesting became a popular way of earning money, and people waded into ponds and then removed and sold the leeches that had become attached to their feet and legs [20]. We can see in the archive documents of Ottoman Empire that France began to import medical leeches with the decrease of leech density in wetland after excessive consumption, from in the Ottoman Empire (1842-1852).

Extensive international trade in Hirudomedicinaliswas identified as a major threat to natural populations, so that it has been listed in Appendix II of the 1987 of Convention on International Trade in Endangered Species of Wild Fauna and Flora. ${ }^{21}$ Exportation and collection of Hirudospecies from nature was restricted with a certain quota by countries included in the CITES convention. In this context Turkey is one of the major exporting countries for the medicinal leech. ${ }^{22-24}$ Turkey allowed to export 2,000 kg of Hirudospecies collected from wetlands between since the year 2014 but was able to only export $364.7 \mathrm{~kg}$ of medical leech in 2016. This amount accounts for only 18,24\% of the export quota permitted. ${ }^{21,25-26}$ As a consequence, all of the leech quota has not been exported, and exportation amount of medicinal leech have declined every year. These decline shows that medicinal leeches are not collected enough from wetlands of Turkey and their population started to decrease as all over Europe.

Nowadays, the U.S. Food and Drug Administration (FDA) has given approval to the use of medicinal leeches for therapeutic purposes, and leeches has been begun intensive use under traditional and complementary medical practices in all the world ${ }^{27}$ Similarly, the use of medicinal leeches for treatment in clinics and hospitals in Turkey have been moved to the legal zone according to traditional and complementary medical practice regulations issued by the Ministry of Health in 2014..$^{28}$ This has greatly increased the use of medical leech in the country. Thus, medical leech export has been started to decline due to excessive use. However, this use must be carefully controlled in order to protect of medical leech species, and the use status of leeches in all the countries should be necessarily recorded. ${ }^{25,29}$

\section{Effect of global climatic change}

Global climatic change, as defined by the U.S. Global Change Research Act of 1990 (GCRA), "means changes in the global environment (including alterations in climate, land productivity, oceans or other water resources, atmospheric chemistry, and ecological systems) that may alter the capacity of the Earth to sustain life". Global warming, increased ocean acidity and rates of biological invasions, green house effects, increase in flood, disproportionate precipitation, melting glaciers, increased rate of
Submit your Article | www.ologyjournals.com/submit-article

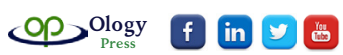


lake evaporation, sea level rise with increased coastal erosions, dried wetlands and disrupted biodiversity are the interacting variables..$^{30}$

The aquatic species are on the top list of the most impacted creatures from global climatic change. In this status, it is estimated that leeches will be much more susceptible to global climate change, which affects all living organisms. The climatic changes will lead to great impact on the leech diversity in aquatic habitat destruction and fragmentation. Perhaps it may cause to disappear some the endangered leech species in the next century.

\section{References}

1. Govedich FR, Bain BA, Moser WE, et al. Annelida (Clitellata) Oligochaeta, Branchiobdellida, Hirudinida, and Acanthobdellida. In Ecology and Classification of Nort American Freshwater Invertebrate. JH Thorp and AP Covich, ed. Academic Press/Elsevier, San Diego, CA. 2010;385-436.

2. Moser WE, Govedich FR, Klemm D. Annelida, Euhirudinea (leeches) In Encyclopedia of Inland Waters. G.E. Likens, ed. Elsevier Ltd, Oxford, UK. 2009;116-123.

3. Saglam N, Sülük Biyolojisi ve Yetiștirme Teknikleri. In Ticari Balık Türlerinin Biyolojisi ve Yetiştirme Teknikleri Hizmetiçi Eğitim Semineri. Tarım ve Koyişleri Bakanlığı, Tarımsal Üretim ve Geliștirme Gn. Md. Su Ürünleri Daire Başkanlığı, Ankara. 2000;51-56.

4. Saglam N. Tıbbi Sülük Biolojisi. In Multidisipliner Yaklaşımlı Biyolojik Temelli Doğal Tedaviler-Biyoterapi (Apiterapi, Hirudoterapi, Maggot Tedavi ve İhtiyoterapi. Tanyüksel M and Mumcuoğlu KY, ed. Parazitoloji Derneği Yayın No: 25. Meta Basım, İzmir. 2015;277-282.

5. Sawyer RT. Leech Biology and Behavior. Clarendon Press, Oxford, United Kingdom. 1986;1-3.

6. Abdualkader AM, Ghawi AM, Alaama M, et al. Leech Therapeutic Applications. Indian J Pharm Sci. 2013;75:127-137.

7. Baskova IP, Khalil S, Nartikova VF, et al. Inhibition of Plasma KallikreinKininase and Kinin-Like Activities of Preparations from the Medicinal Leeches. Thromb Res. 1992;67:721-730.

8. Baskova IP, Yudina TG, Zavalova LL, et al. Protein-Lipid Particles of Medicinal Leech Salivary Gland Secretion; Their Size and Morphology. Biochemistry-Moscow. 2010;75:585-589.

9. Seleznev KG, Shchetinina EA, Trophimenko NP, et al. Use of the Medicinal Leech in the Treatment of Ear Diseases. ORL J Otorhinolaryngol Relat Spec. 1992;54:1-4.

10. Zaidi SMA, Jamee SS, Zaman F, et al. A Systematic Overview of the Medicinal Importance of Sanguivorous Leeches. Altern Med Rev. 2011;16:59-65.

11. Saglam N. Basic Principles of Breeding of Medicinal Leech, Hirudo verbana. In International Scientific Conference (Caucasus ecosystem: Past, Present and Future (80 years of the zoological investigations of the Caucasus). E Yusifov, ed. AMEA Zoologiya Institut, Bakı/Azerbaijan. 2017a;501-506.

12. Saglam N, Saunders R, Lang SA, et al. A new species of Hirudo (Annelida: Hirudinidae): historical biogeography of Eurasian medicinal leeches. BMC Zool. 2016;1:1-12.

13. AGDE. Wetlands and agriculture. Australian Government Department of the Environment. (2016).
14. Sumpter JP. Endocrine Disrupters in the Aquatic Environment: An Overview. Acta hydrochimica et hydrobiologica. 2005;33:9-16.

15. Wang Y, Zhou J. Endocrine disrupting chemicals in aquatic environments: A potential reason for organism extinction? Aquat Ecosyst Health Manag. 2013;16:88-93.

16. RAMP. Human Influences on Aquatic Ecosystems. Regional Aquatics Monitoring Program. 2018.

17. Cuffney TF, Zappia H, Giddings EMP, et al. Effects of urbanization on benthic macroinvertebrate assemblages in contrasting environmental settings: Boston, Massachusetts; Birmingham, Alabama; and Salt Lake City, Utah. Effects of Urbanization on Stream Ecosystems. 2005;47:361-407

18. Richardson EV, Simons DB, Lagasse PF. River Engineering for Highway Encroachments. In Highways in the River Environment. U.S. Department of Transportation, National Highway Institute. Washington, DC. 2001;646.

19. Trombulak SC, Frissell CA. Review of ecological effects of roads on terrestrial and aquatic communities. Conservation Biology. 2000; $14: 18-30$.

20. Whitaker IS, Rao J, Izadi D, et al. Historical Article: Hirudo medicinalis: ancient origins of, and trends in the use of medicinal leeches throughout history. Br J Oral Maxillofac Surg. 2004;42: 133-137.

21. CITES, CITES Trade Database. Convention on International Trade in Endangered Species of Wild Fauna and Flora (CITES). 2017.

22. Kasparek M, Demirsoy A, Akbulut A, et al. Distribution and status of the medicinal leech (Hirudo medicinalis L.) in Turkey. Hydrobiologia. 2000;441:37-44.

23. Saglam N, Dorucu M, Ozdemir Y, et al. Distribution and economic importance of medicinal leech, Hirudo medicinalis (Linnaeus, 1758) in Eastern Anatolia/Turkey. Lauterbornia. 2008;65:105-118.

24. Trontelj P, Sotler M, Verovnik R. Genetic differentiation between two species of the medicinal leech, Hirudo medicinalis and the neglected Hirudo verbana, based on random-amplified polymorphic DNA. Parasitol Res. 2004;94:118-124.

25. Saglam N. The Economic Importance and Status of Medical Leeches in Turkey. In International Scientific Conference (Caucasus ecosystem: Past, Present and Future (80 years of the zoological investigations of the Caucasus). E Yusifov, ed. AMEA Zoologiya Institut, Bak1/Azerbaijan; 2017b;495-500.

26. Saglam N. Dünya sülük ticareti ve Türkiye'nin durumu. In 1. Ulusal Sülük Çalıştayı, 27-28 Nisan 2017. N Saglam and O Ozbay, ed. Gıda Tarım ve Hayvancılık Bakanlığı, Elazı̆̆ Su Ürünleri Araştırma Enstitüsü Müdürlüğü, Elazı ̆. 2017c.

27. FDA. Indications for Use of Medicinal Leeches (Hirudo medicinalis). U.S. Food and Drug Administration.2004;5.

28. Anonim, Geleneksel ve Tamamlayıcı Tıp Uygulamaları Yönetmeliği. 27 Ekim 2014 tarih ve 29158 sayılı Resmi Gazete. Sağlık Bakanlığı, Ankara. 2014.

29. Saglam N. Protection and sustainability, exportation of some species of medicinal leeches (Hirudo medicinalis L, 1758 and Hirudo verbana Carena, 1820). Journal of FisheriesSciences.com. 2011;5:1-15.

30. Eissa AE, Zaki MM. The impact of global climatic changes on the aquatic environment. Procedia Environmental Sciences. 2011;4:251-259. 